\section{Effects of Storage Temperature, Storage Atmosphere, and Growing Region on Internal Browning Disorder of 'McIntosh' Apples}

\author{
C.L. Chu
}

Additional indeX wORds. flesh browning, storage temperature, storage atmosphere, controlled atmosphere, low oxygen, growing region, Malus domestica M cl ntosh

Summary. 0 ur study found that storage temperature, storage atmosphere and growing region interactively affect the probability of internal browning disorder in 'M cl ntosh' apples (Malusdomestica Borkh.). $H$ igher incidence of internal browning occurred in apples stored for 6 months at $1{ }^{\circ} \mathrm{C}\left(34^{\circ} \mathrm{F}\right)$ in controlled atmosphere (CA) with $\mathbf{2 . 5 \% \mathrm { O } _ { 2 } +}$ $1.5 \% \mathrm{CO}_{2}$ or in CA with $1.0 \% \mathrm{O}_{2}+$ $0.5 \% \mathrm{C} \mathrm{O}_{2}$ than apples stored at $1^{\circ} \mathrm{C}$ in air or stored at $3{ }^{\circ} \mathrm{C}\left(37^{\circ} \mathrm{F}\right)$ in air or C A conditions. The magnitude of the incidence of internal browning varied among apples harvested from different growing regions. Apples from London, O ntario, C anada were less tolerant to these two storage conditions and therefore greater number of fruit developed internal browning than apples from other regions. In addition, apples from the

$\mathrm{H}$ orticultural Research Institute of O ntario, D epartment of Plant Agriculture, U niversity of G uelph, 4890 Victoria Avenue N orth, Vineland Station, O ntario LOR 2E0, Canada.

This research was supported by a grant from the O ntario M inistry of Agriculture, Food and Rural Affairs (OMAFRA). Supports from the Ontario Apple $M$ arketing Commission, participating growers and O M AFRA H orticultural Crop Advisers made this research possible. The author also acknowledge the help and advice of William M athes-Sears with statistical consultation and the PROC MIXED analysis in the SAS procedures. The cost of publishing this paper was defrayed in part by the payment of page charges. U nder postal regulations, this paper therefore must be hereby marked advertisement solely to indicate this fact.
London growing region and stored at $1{ }^{\circ} \mathrm{C}$ in CA with $1.0 \% \mathrm{O}_{2}+0.5 \% \mathrm{CO}_{2}$ had greater probability of internal browning than apples stored at $1{ }^{\circ} \mathrm{C}$ in $\mathrm{CA}$ with $2.5 \% \mathrm{O}_{2}+1.5 \% \mathrm{CO}_{2}$. $\mathrm{H}$ owever, there was no difference between these two C A storage conditions in causing internal browning among apples harvested from other three growing regions. Few apples showed internal browning when they were stored at $3{ }^{\circ} \mathrm{C}$, no matter of what storage atmosphere was used. Therefore, internal browning disorder can be avoided or significantly reduced by storing apples at 3 instead of $1{ }^{\circ} \mathrm{C}$, in these two CA conditions. Internal browning disorder will not be a risk if apples are stored in air at 1 or $3{ }^{\circ} \mathrm{C}$.

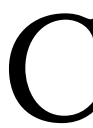

ommercial storage operators in O ntario delivered apple samples to our research laboratory in March of 1992 . These storage operators reported a similar problem in 'Mclntosh' apples after removal from commercial CA storage rooms. The apples had developed diffused browning in the flesh, with no definite outline on the affected tissue. This physiological disorder is known as internal browning ( $M$ eherick et al., 1994). It has also been called "flesh browning". I nternal browning disorder may affect the outer flesh, the tissue around the core, or both. In more advanced stages, browning may encompass most of the internal tissue of the fruit. R esearchers in other areas of North America, such as Q uebec, $\mathrm{C}$ anada and $\mathrm{N}$ ew York, U nited States, also reported observation of this problem in 1992. This disorder was also reported in British C olumbia, $\mathrm{C}$ anada, in the spring of 1993 and again in Q uebec in the spring of 1997.

I nternal browning has been associated with pre- and postharvest conditions. Preharvest conditions include cool growing temperatures, shaded parts of the tree, large fruit, lightly cropped trees, high nitrogen level, low tree vigor, and tree age (Ballard et al., 1922; H enze, 1971; M eheriuk et al., 1984, 1994; O verholzer et al., 1923; Powell, 1909; Schouten, 1986; Winkler, 1923). DeE II and Prange (1993) reported that conventionally grown 'M clntosh' apples had a higher probability of internal browning after 8 months of CA storage than organically grown fruit. I nternal browning normally does not develop in ' $\mathrm{M} \mathrm{Cl}$ tosh' applescold stored in air. Postharvest factors associated with internal browning include late harvesting, delayed cold storage, storage temperature that is too cold, high $\mathrm{CO}_{2}$ level in CA storage, and sometimes, water core (Acki et al., 1981; Meheriuk et al., 1984). Internal browning occurs in many apple cultivars ( $M$ eheriuk et al., 1994).

I nternal browning often develops in ' $\mathrm{M}$ clntosh' apples when they are stored under $\mathrm{CA}$ at $0^{\circ} \mathrm{C}\left(32^{\circ} \mathrm{F}\right)$. In O ntario, we recommend storing 'M clntosh' apples at $3^{\circ} \mathrm{C}\left(37^{\circ} \mathrm{F}\right)$. H owever, some commercial storage operators store them at 0 or $1^{\circ} \mathrm{C}$ (32 or $34^{\circ} \mathrm{F}$ ) to accommodate mixed varieties of apples stored in the same CA room. These operators do not recognize the risk for developing internal browning in ' $\mathrm{M}$ cl ntosh' apples stored below $3^{\circ} \mathrm{C}$ in CA storage.

The objective of this study was to evaluate the effects of storage temperature, storage atmosphere and growing region on the probability of internal browning in 'M clntosh' apples. Information provided in this study will help alert storage operators to the risk of developing internal browning, and enable them to adjust storage conditions accordingly.

\section{Materials and methods}

Sources of APPLE SAMPLes. Eight commercial orchardsfrom each of four apple-growing regions in O ntario, Canada(Simcoe, Smithfield, G eorgian Bay, and London) participated in this 1994 project. O rchards in the Simcoe area are located at the north side of $L$ ake $E$ rie on the north shore of $L$ ong Point Bay close to the city of Simcoe. Orchards in the Smithfield area are located at the north shore of Lake O ntario close to the cities of T renton and Colborne. O rchards in the Georgian Bay area are located at the southern tip of the G eorgian Bay close to the cities of M eaford and Thornsbury. O rchards in the London area are located inland between $\mathrm{L}$ ake $\mathrm{H}$ uron and $L$ ake E rie close to the cities of $L$ ondon and Woodstock.

Apples were harvested from each orchard at an optimum harvest date that was determined by the commercial grower and the provincial horticulture crop advisor. The apples were transported from the orchard to the $\mathrm{H}$ orticultural Products Laboratory at 
T able1. T ests of fixed effects of the probability of internal browning in ' $\mathrm{M}$ cl ntosh' apples after storage for 6 months at 1 or $3{ }^{\circ} \mathrm{C}$ ( 34 or $37{ }^{\circ} \mathrm{F}$ ) in air, controlled atmosphere (C A) with $2.5 \% \mathrm{O}_{2}+1.5 \% \mathrm{CO}_{2}$ or $\mathrm{CA}$ with $1.0 \% \mathrm{O}_{2}+0.5 \% \mathrm{CO}_{2}$, and followed by $7 \mathrm{~d}$ at $20^{\circ} \mathrm{C}\left(68{ }^{\circ} \mathrm{F}\right)$ in air.

\begin{tabular}{lrcc}
\hline & \multicolumn{3}{c}{ Tests of fixed effects $^{\mathbf{2}}$} \\
\cline { 2 - 4 } Source & df & M ean square & P > F \\
\hline Growing region (G) & 3 & 14.16 & $*$ \\
M ain plot error & 28 & 3.63 & $* *$ \\
Temperature (T) & 1 & 171.68 & $* *$ \\
Atmosphere (A) & 2 & 44.43 & $* *$ \\
$\mathrm{~T} \times \mathrm{A}$ & 2 & 28.37 & $* *$ \\
$\mathrm{G} \times \mathrm{T}$ & 3 & 12.14 & $*$ \\
$\mathrm{G} \times \mathrm{A}$ & 6 & 4.26 & $\mathrm{NS}$ \\
$\mathrm{G} \times \mathrm{T} \times \mathrm{A}$ & 6 & 3.34 & \\
Subplot error & 138 & 1.85 & \\
\hline
\end{tabular}

${ }^{2} \mathrm{D}$ ata are transformed to logit values for SAS analysis using PROC M IXED procedure.

Vineland Station on the day of harvest. The apples were not washed or waxed before storage. Apples from all four growing regions were harvested in 1 week.

Storage conditions. Six storage rooms (inside dimension: $1.9 \mathrm{~m}$ width $\times 1.9 \mathrm{~m}$ depth $\times 3.1 \mathrm{~m}$ height, with a drop ceiling $2.2 \mathrm{~m}$ from the floor [ 75 inches width $\times 75$ inches depth $\times 122$ inches height, with a drop ceiling 87 inches from the floor]) were used in this experiment (Chu et al., 1985). The rooms are prefabricated walk-in coolers made airtight with Steridex paint on the inside wall, ceiling, and floor surfaces. Apples were stored at 1 or $3{ }^{\circ} \mathrm{C}\left(34\right.$ or $37^{\circ} \mathrm{F}$ ) in three different atmosphere conditions: 1) air, 2) CA with $2.5 \% \mathrm{O}_{2}+1.5 \% \mathrm{CO}_{2}$ balance $\mathrm{N}_{2}$, or 3) $\mathrm{CA}$ with $1.0 \% \mathrm{O}_{2}+0.5 \% \mathrm{CO}_{2}$ balance $\mathrm{N}_{2}$. The storage room temperature was controlled continuously by a computer system ( $\mathrm{H}$ antec $\mathrm{C}$ ontrols, Pickering, O ntario) with high and low alarm levels set at $1{ }^{\circ} \mathrm{C}\left(2^{\circ} \mathrm{F}\right)$ above and below the preset room temperature. The atmosphere in all CA rooms were automatically monitored and adjusted by a computer-controlled gas sampling system. The atmosphere was controlled by adding nitrogen, carbon dioxide or air; with a computer-controlled gas sampling system (Chu et al., 1985). The atmosphere in each CA room was monitored and corrected twice per day. Atmosphere levels for each room were also checked manually with an oxygen and carbon dioxide anal yzer ( $N$ ova A nalytical Systems I nc., $\mathrm{H}$ amilton, O ntario) sometime during the weekdays by sampling the room atmosphere through a valve on the door in order to verify the computerized system. The relative humidity levels in all storage rooms weremaintained at levels between $90 \%$ and $95 \%$. Apples were stored in stackable plastic containers, allowing good air circulation through the fruit.

StORAGE DURATION AND LABORATORY EVALUATION OF INTERNAL BROWNING DISORDER IN APPLES. Apples were stored for 4 or 6 months. After each storage period plusadditional $7 \mathrm{~d}$ at $20^{\circ} \mathrm{C}\left(68^{\circ} \mathrm{F}\right)$ in air, 10 apples, randomly sampled from each orchard and storage condition, were evaluated. $D$ ata for internal browning was recorded by counting the number of apples showing the symptom. M ost apples with the symptom showed only slight severity of internal browning.

Statistical design and analyses. A completely randomized split-plot design by each storage duration, with growing region as main plot and storage temperature and storage atmosphere as subplots, was used in the statistical analysis of the data. Theeight orchards in each growing region were considered replications. Ten apples in each laboratory evaluation were a samplefor each factor. We used PR O C MIXED procedure of the Statistical

Table 2 Results of fixed ffects of the probability of internat browning in ' $\mathrm{Mcl}$ ntosh' apples after storage for 6 months at 1 or $3^{\circ} \mathrm{C}\left(34\right.$ or $\left.37{ }^{\circ} \mathrm{F}\right)$ in air, controlled atmosphere (CA) with $2.5 \% \mathrm{O}_{2}+1.5 \% \mathrm{CO}_{2}$ or CA with $1.0 \% \mathrm{O}_{2}+0.5 \%$ $\mathrm{CO}_{2}$, and followed by $7 \mathrm{~d}$ at $20^{\circ} \mathrm{C}\left(68^{\circ} \mathrm{F}\right)$ in air.

\begin{tabular}{lccc}
\hline \multirow{2}{*}{ Source } & \multicolumn{3}{c}{ C ontrast statement results $^{\mathbf{z}}$} \\
\cline { 2 - 4 } Growing region $(\mathrm{G})$ at $1{ }^{\circ} \mathrm{C}$ & 3 & $\mathbf{~ F}$ & $\mathbf{P}>\mathbf{F}$ \\
Growing region at $3{ }^{\circ} \mathrm{C}$ & 3 & 9.33 & $* *$ \\
Atmosphere $(\mathrm{A})$ at $1{ }^{\circ} \mathrm{C}$ & 2 & 0.44 & $\mathrm{NS}$ \\
Atmosphere at $3{ }^{\circ} \mathrm{C}$ & 2 & 38.41 & $* *$ \\
$\mathrm{G} \times \mathrm{A}$ at $1{ }^{\circ} \mathrm{C}$ & 6 & 1.15 & $\mathrm{NS}$ \\
$\mathrm{G} \times \mathrm{A}$ at $3{ }^{\circ} \mathrm{C}$ & 6 & 4.58 & $\mathrm{NS}$ \\
\hline
\end{tabular}

${ }^{2} \mathrm{D}$ ata are transformed to logit values for SAS analysis using PROC M IXED procedure. 
ity of internal browning disorder in 'M clntosh' apples (Table 1). There was very strong interaction between temperature and atmosphere and between temperature and growing region. Also, there was an interaction between atmosphere and growing region. There was a suggestion of an interaction among the three factors (not quite significant at 5\% level, though asP valueis 0.0981 ). T o clarify the interaction among the three factors, CONTRAST statements were used in PROC MIXED to allow independent analysis of 1 and $3^{\circ} \mathrm{C}$ ( 34 and $37^{\circ} \mathrm{F}$ ) data. The CONTRAST statement results show that when apples were stored at $1{ }^{\circ} \mathrm{C}$, the interactive effect of atmosphere and region was highly significant (Table 2 ). When apples were stored at $3{ }^{\circ} \mathrm{C}$, the interactive effect of atmosphere and region was not significant. In order to effectively present all two-factorial interactions in Table 1 and the interaction between atmosphere and growing region under $1^{\circ} \mathrm{C}$ in Table 2, all simple effects were examined and presented (Fig. 1).

Apples showed internal browning only when they were stored in CA conditions at $1^{\circ} \mathrm{C}$. Since very few or no symptoms were evident after apples were stored at 1 or $3^{\circ} \mathrm{C}$ in air (cold storage), internal browning does not appear to be related to chilling injury. Apples stored at $3{ }^{\circ} \mathrm{C}$ under all three atmospheres showed very few or no symptoms, so the disorder also does not appear to berelated to low-oxygen injury. This suggests that internal browning was caused by an interactive effect between low temperature and low-oxygen atmosphere.

Internal browning appeared most frequently when apples were stored at $1{ }^{\circ} \mathrm{C}$ after 6 months in these two CA conditions. The severity of the probability of apples showing the symptom depended upon which growing region the appleswereharvested from. Apples from London region had a greater probability of internal browning than apples from the other three regions (Fig. 1, mean separation indicated by uppercase letters). For example, after storage at $1{ }^{\circ} \mathrm{C}$ in $\mathrm{CA}$ with $1.0 \% \mathrm{O}_{2}+$ $0.5 \% \mathrm{CO}$, approximately $60 \%$ of apples harvested from $L$ ondon region showed the internal browning, while $<5 \%$ of apples harvested from Simcoe region had the symptoms. In addition, for apples harvested from $L$ ondon region, apples stored at $1{ }^{\circ} \mathrm{C}$ in CA with $1.0 \%$ $\mathrm{O}_{2}+0.5 \% \mathrm{CO}_{2}$ had more internal browning than apples stored at the same temperature in CA with $2.5 \% \mathrm{O}_{2}$ $+1.5 \% \mathrm{CO}_{2}$ (Fig. 1, mean separation indicated by lowercase letters).

Climate conditions within each region might affect the initiation and development of the internal browning. Meheriuk et al. (1994) and O verholzer et al. (1923) suggested that cool growing temperature might be one of the many possible factors affecting the probability of internal browning disorder. This disorder was not reported by commercial apple growers in Ontario in the spring of 1994 (for the 1993 crop) but was reported in the spring of 1995 (for the 1994 crop), it could bebecausewehad warmer August temperatures in 1993 and colder August temperatures in 1994.

The storage room temperature was maintained within $\pm 0.2^{\circ} \mathrm{C}(0.4$ ${ }^{\circ} \mathrm{F}$ ) of the set temperature through the duration of the experiment except for three incidences the temperature of a storage room rose to above the alarm level of $\pm 1{ }^{\circ} \mathrm{C}\left(2^{\circ} \mathrm{F}\right)$. The first incidence occurred on $70 \mathrm{ct} .1994$, in the $2.5 \% \mathrm{O}_{2}+1.5 \% \mathrm{CO}_{2} \mathrm{CA}$ room, the temperature raised from $3^{\circ} \mathrm{C}$ to $13^{\circ} \mathrm{C}$ $\left(55^{\circ} \mathrm{F}\right)$ over a $24-\mathrm{h}$ period. The second incidence occurred on $26 \mathrm{~J}$ an. 1995 , in the cold storage room, the temperature raised from 3 to $12{ }^{\circ} \mathrm{C}$ $\left(54^{\circ} \mathrm{F}\right.$ ) over a $24 \mathrm{~h}$ period. The third incidence occurred on $27 \mathrm{Feb} .1995$, in the $1.0 \% \mathrm{O}_{2}+0.5 \% \mathrm{CO}_{2} \mathrm{CA}$ room, the temperature raised from 1 to $8{ }^{\circ} \mathrm{C}$ $\left(46^{\circ} \mathrm{F}\right.$ ) over a $24-\mathrm{h}$ period. These incidences were quickly handled by either fixing the refrigeration system or by moving the fruit to another storage room. D uring the 6 month of storage, the standard deviation of oxygen levels in CA or low-oxygen CA room was $\pm 0.4 \%$ or $\pm 0.5 \%$, respectively. The standard deviation of carbon dioxide levels in CA or low-oxygen $C A$ room was $\pm 0.6 \%$ or $\pm 0.8 \%$, respectively.

\section{Recommendation to storage operators}

During a year when internal browning disorder in apples may occur, a greater probability of this disorder can be expected after 6 months of CA storage if the room temperature is $1{ }^{\circ} \mathrm{C}\left(34^{\circ} \mathrm{F}\right)$. Therefore, we recommend that ' $\mathrm{M}$ Clntosh' apples should bestored at $3^{\circ} \mathrm{C}\left(37^{\circ} \mathrm{F}\right)$ in CA rooms. We do not recommend that storage operatorsstore 'M cl ntosh' appleswith

Fig. 1. Probability of internal browning disorder after apples were stored for 6 months at 1 or $3^{\circ} \mathrm{C} \mathrm{(34}$ or $37^{\circ} \mathrm{F}$ ) in air, controlled atmosphere (CA) with $2.5 \% \mathrm{O}_{2}+\mathbf{1 . 5} \%$ $\mathrm{CO}_{2}$, or C A with $1.0 \% \mathrm{O}_{2}+0.5 \%$ $\mathrm{CO}_{2}$, and followed by $7 \mathrm{~d}$ at $20^{\circ} \mathrm{C}$ $\left(68^{\circ} \mathrm{F}\right)$ in air. Mean separation (shown in lowercase letters) within each growing region by protected LSD test, 5\% level. Mean separation (shown in uppercase letters) within C A storage conditions at $1{ }^{\circ} \mathrm{C}$ by protected LSD test, $5 \%$ level.

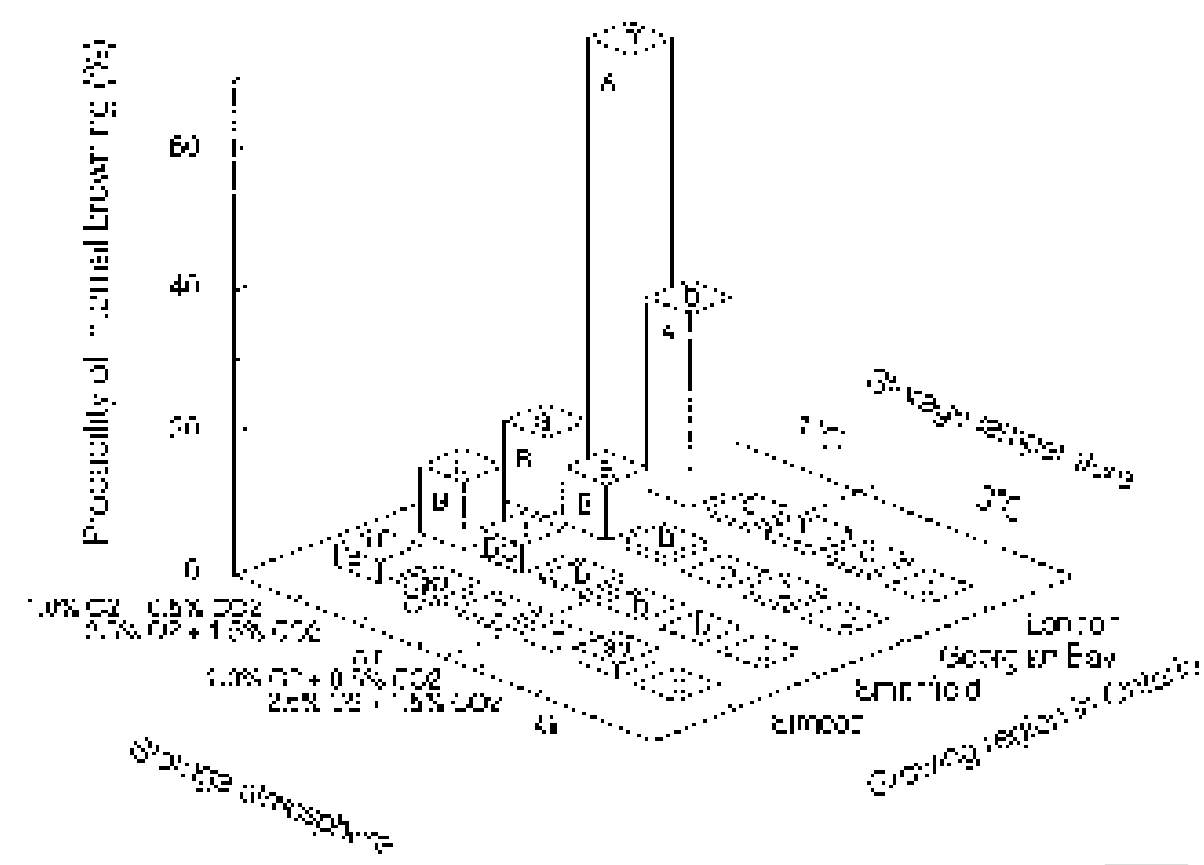


other apple cultivars in the same CA storage room at $1{ }^{\circ} \mathrm{C}$.

O ur results have shown that lowering the temperature from 3 to $1^{\circ} \mathrm{C}$ during storage in air did not increase the number of apples that developed internal browning. Therefore, ' $\mathrm{M} \mathrm{cl}$ ntosh' apples may be stored with other apple cultivars in air at $1^{\circ} \mathrm{C}$.

A pplesgrown in someregion may be less tolerant to extreme storage condition (e.g., CA conditions at 1 ${ }^{\circ} \mathrm{C}$ ) and therefore greater number of fruit will develop internal browning than apples from other regions. Storage operators for this region must follow thestoragerecommendation more closely or develop their own proper apple storage condition for their region.

A pples can show internal browning disorder after 6 months of storage even when there is no symptom after 4 months of storage. Therefore, apples showing no symptom during early sampling from storage does not mean apples will be free from this disorder when storage duration is extended.

\section{Literature cited}

Acki, S., S. Suzuki, and T. T amura. 1981. Internal browning of 'Starking D elicious' apples during low temperature storage. Rpt. N atl. Food. Res. Inst. (Tokyo) No. 38:56-61.

Ballard, W.S., J.R. M agness, and L.A. $\mathrm{H}$ awkins. 1922. Internal browning of the Yellow N ewtown apple. U SD A Bul. 1104.

Chu, C.L., R.B. Smith, and E.M. Lauro. 1985. N ew CA storage research facilities at the Horticultural Research Institute of O ntario, p. 229-234. In: S.M. Blankenship (ed.). C ontrolled atmo spheresfor storage and transport of perishableagricultural commodities. Proc. 4th Controlled A tmosphere Research Conf., Raleigh, N.C.

DeEII, J.R. and R.K. Prange. 1993. Postharvest physiological diso rders, diseasesand mineral concentrations of organically and conventionally grown ' $\mathrm{Mcl}$ ntosh' and 'Cortland' apples. Can. J. Plant Sci. 73:223230.

H enze, J. 1971. Flesh browning in Cox's Orange Pippin. Erwerobstbau 13:197200.

M eheriuk, M., O.L. Lau, and J.W. H all. 1984. Effects of some postharvest and storage treatments on the incidence of flesh browning in controlled-atmospherestored 'D elicious' apples. J. Amer. Soc. H ort. Sci. 109:290-293.

M eheriuk, M ., R.K. Prange, P.D. Lidster, and S.W. Porritt. 1994. Postharvest disorders of apples and pears. Agr. Can. Publ. $1737 / \mathrm{E}$.

O verholzer, E.I., A.J. Winkler, and H.E. Jacob. 1923. Factors influencing the development of internal browning of the Yellow N ewtown apple. U niv. Calif. Expt. Sta. Bul. 370.

Powell, G.H . 1909. Internal browning of apples. I ce and R efrigeration, Vol. 36:8-9.

SAS. 1997. SAS/ ST AT software: Changes and enhancements through release 6.12. SAS I nstitute Inc., Cary, N .C.

Schouten, S.P. 1986. N otes on the occurrence in 1985/ 86 of internal browning in apples. Fruitteelt 76:1036-1039.

Winkler, A.J. 1923. Internal browning of the Yellow N ewtown apple. J. Agr. Res. 24:165-184.
Incorporating Water Harvesting into Plasticulture Production of Muskmelon

\author{
Frank J. D ainello, ${ }^{1}$ \\ L arry Stein, ${ }^{2}$ G uy Fipps, ${ }^{3}$ and \\ Kenneth White ${ }^{4}$
}

AdDITIONAL INDEX WORDS. water conservation, rainfall capture, trench planting, plastic mulch, water catchments, cucumis melo, cantaloupe, irrigation, seed bed configuration

Summary. Competition for limited water supplies is increasing world wide. E specially hard hit are the irrigated crop production regions, such as the Lower Rio $\mathbf{G}$ rande Valley and the Winter $\mathbf{G}$ arden areas of south T exas. To develop production techniques for reducing supplemental water needs of vegetable crops, an ancient water harvesting technique called rainfall capture was adapted to contemporary, large scale irrigated muskmelon (C ucumismelo var. reticulatusL.) production systems. The rainfall capture system developed consisted of plastic mulched miniature water catchments located on raised seed beds. This system was compared with conventional dry land and irrigated melon production. $R$ ainfall capture resulted in $108 \%$ average yield increase over the conventional dry land technique. When compared with conventional furrow irrigation, rainfall capture increased marketable muskmelon yield as much as 5355 lb/ acre $\left(6000 \mathrm{~kg} \cdot \mathrm{ha}^{-1}\right)$. As anticipated,

The cost of publishing this paper was defrayed in part by the payment of page charges. U nder postal regulations, this paper therefore must be hereby marked advertisement solely to indicate this fact.

${ }^{1}$ Professor and extension horticulturist, D epartment of $\mathrm{H}$ orticultural Sciences, Texas A\& M U niversity, College Station, TX 77843-2134.

${ }^{2}$ Associate professor and extension horticulturist T exas Agricultural Extension Service, T exas Agricultural Research and Extension Center, U valde, TX 788021849.

${ }^{3}$ Associate professor and extension agricultural engineer, D epartment of Agricultural Engineering, T exas A\& M U niversity, College Station, TX 77843-2134.

${ }^{4} \mathrm{C}$ ounty extension agent-agriculture. 